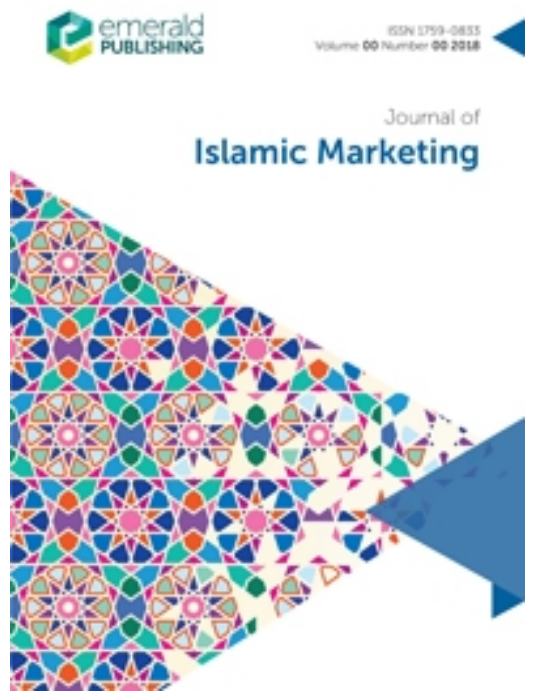

\title{
Antecedents of Halal Brand Equity: A Study of Halal Food Sector of Malaysia
}

\begin{tabular}{|r|l|}
\hline Journal: & Journal of Islamic Marketing \\
\hline Manuscript ID & JIMA-01-2021-0012.R1 \\
\hline Manuscript Type: & Research Article \\
\hline Keywords: & $\begin{array}{l}\text { Halal brand trust, halal brand satisfaction, halal brand image, halal brand } \\
\text { equity }\end{array}$ \\
\hline
\end{tabular}

\section{SCHOLARONE \\ Manuscripts}




\title{
Antecedents of Halal Brand Equity: A Study of Halal Food Sector of Malaysia
}

\begin{abstract}
Purpose - Islamic marketing is an emerging field with a lot of potentials, so it is worthwhile to explore it. This study aims to conduct research on the unexplored relationship of antecedents of the equity, image, and consumers' trust and satisfaction of halal brands.

Design/methodology/approach - A structured questionnaire was designed to conduct research to analyze the halal brand equity and its antecedents. Data were collected from 250 halal consumers of Kota Samarahan and Kuching, Malaysia through a self-administered questionnaire using a convenience sampling method.

Findings -The study finds a positive relationship of three antecedents of brand equity which confirms a strong relationship between the image and satisfaction of halal brand equity. The results further showed that halal brand image is linked with halal brand trust but the relationship between halal brand trust and its equity could not be proved.

Originality - Islamic marketing has received great attention of researchers, academicians, and practitioners which has rather been unexplored earlier particularly the relationships among antecedents of the equity, image, and consumers' trust and satisfaction of halal brands.

Research Limitations -This has been a cross-sectional study that was limited to Malaysia, a Muslim majority country. Researchers can conduct a longitudinal study and can conduct it in non-Muslim societies to comprehend their diversity and wider impact. Additionally, this study was limited to halal food brands in Malaysia.
\end{abstract}

Keyword: Halal brand trust, halal brand satisfaction, halal brand image, halal brand equity 


\section{Introduction}

Halal brands offer traditional benefits of brands along with Shariah compliancy while aiming to capture their niche as halal brands (Alam and Sayuti, 2011). In recent years, Islamic branding is gaining ground in the whole world due to multiple reasons. First, in terms of the increase in the number of followers, Islam is expeditiously expanding religion in the different corners of the world (Ireland and Rajabzadeh, 2011). Second, the Muslim population is rising and it can be the largest population by 2070 (Hackett, 2017). Third, because of a large consumer market, their volume of market shares is also big. This situation makes it more relevant and it hints at the rising demand for Shariah-compliant products.

In the context of an increase in demand for halal (permissible) products, it has been noted that the halal food market is gaining momentum and by 2023 it can surpass a colossal $\$ 1.9$ tn (Dubai Islamic Economy Development Centre, 2018). These developments encouraged multinationals like Unilever, McDonald's, L'Oreal, and Nestle to introduce Shariahcompliant products among their consumers in respective Islamic consumers market (IzberkBilgin and Nakata, 2016).

Due to the above-mentioned reasons, including the large consumer base, better opportunities for companies in Muslim dominant markets, and the addition of halal product lines, it becomes a lucrative opportunity for the companies and market researchers to focus upon manufacturing halal or Islamic products. Brand equity is an invisible capital for enterprises and it increases their worth (Neal and Strauss, 2008). Hence, this study addresses halal brands because their increased attention on halal brands will increase their brand equity. Building brand equity resulted in a better competitive advantage, better opportunities for brand extension, and benefits in the margin (Chen, 2010).

Keeping in view the importance of halal brands and their wide acceptance among large Muslim consumer markets, it is important to study the constructs that could determine the image, consumer trust and satisfaction, and equity of halal brands. Although (Butt et al., 2017) introduced and discussed halal brand equity (HBE) but did not explore the internal and mutual relationship of the image, consumer trust and satisfaction, and equity of halal brands. So, this study is significant in several aspects. First, it aims to explore this type of mutual relationship between the target constructs. Second, it provides the research framework for the enhancement of the equity of the halal brand from its image and consumers' trust and satisfaction. Third, it aims to present the literature review about the Islamic branding upon which a new managerial framework in this area would be suggested. The study aims to contribute in terms of presenting the investigation about HBE and the mutual relationship among halal brand image (HBI), consumer trust, and satisfaction. It further aims to present the empirical study of the relationship. With the presentation of the new concepts of HBI, halal brand trust (HBT), and halal brand satisfaction (HBS), the study aims to present clarity about the concepts.

Halal food is easily available in the market, but there are numerous concerns of consumers about halal food (Fadzlillah et al., 2011). One of the main reasons for doubts about halal food is that many foreign companies and non-Muslims are operating the business of halal food so consumers show their doubts about halal food (Mohamed et al., 2020). It is also known that consumers' concept of halal is also limited (Alam and Sayuti, 2011). Therefore, it is important to understand and investigate the halal food sector. Furthermore, the study is conducted to understand consumers of halal food in Malaysia to improve comprehension and layout guidelines for business managers so that they could make better strategies for their consumers.

Malaysia has captured a unique position in terms of halal as it is the only country that has a government body such as the Islamic Department of Malaysia or Jabatan Kemajuan Islam Malaysia (JKIM) to look into halal matters including halal in restaurants, shops, and 